\title{
OVERVIEW OF THE WORKSHOP ON SECULAR VARIATIONS IN PRODUCTION RATES OF COSMOGENIC NUCLIDES ON EARTH ${ }^{1}$
}

\author{
JOHN C. GOSSE, ${ }^{2}$ ROBERT C. REEDY, ${ }^{3}$ CHARLES D. HARRINGTON ${ }^{4}$ and JANE POTHS
}

Los Alamos National Laboratory, Los Alamos, New Mexico 87545 USA

\section{INTRODUCTION}

Measurements of cosmogenic nuclides made in situ in the Earth's surface are being used to help resolve a wide range of geologic and chronologic questions. Cosmogenic nuclides $\left({ }^{3} \mathrm{He},{ }^{10} \mathrm{Be},{ }^{14} \mathrm{C}\right.$, ${ }^{21} \mathrm{Ne},{ }^{26} \mathrm{Al},{ }^{36} \mathrm{Cl}$ are presently used) can reveal rock exposure history information leading to estimates of timing of surface forming events, rates and styles of erosion, and timing and durations of episodes of burial. Depending on the problems being tackled, a significant source of error $( \pm 10$ $25 \%$ ) for any cosmogenic nuclide method is the present uncertainty in the spatial and temporal variability of the rates of production of these in-situ nuclides.

The Workshop on the Secular Variations in the Rates of Production of Cosmogenic Nuclides on Earth was hosted by Los Alamos National Laboratory on 2-5 February 1996 in Santa Fe, New Mexico. The workshop was a multi-disciplinary, international meeting of 38 scientists from seven countries (see below). The workshop gathered together not only geologists, chemists and physicists directly involved in the determination of in-situ production rates, but also workers in the related fields of paleomagnetism, nuclear cross sections, cosmic-ray transport and other branches of geochronology. This is a cross section of scientists that would never be found at any single societal meeting.

\begin{tabular}{ll}
\multicolumn{2}{l}{ List of Attendees } \\
Bierman, P. & University of Vermont \\
Brook, E. & University of Rhode Island \\
Brown, E. & CNRS-IN2P3, France; University of Minnesota \\
Caffee, M. & Lawrence Livermore National Laboratory \\
Clapp, E. & University of Vermont \\
Clark, D. & University of Washington \\
Damon, P. & University of Arizona \\
Dunne, A. & PRIME Lab, Purdue University \\
Evenson, E. & Lehigh University \\
Finkel, R. & Lawrence Livermore National Laboratory \\
Flinsch, M. & New Mexico Tech \\
Gillespie, A. & University of Washington \\
Gosse, J. & Los Alamos National Laboratory \\
Graham, I. & Institute of Geological and Nuclear Sciences, NZ \\
Graf, Th. & University of California, San Diego; ETH Zürich \\
Harrington, C. & Los Alamos National Laboratory \\
Heisinger, B. & Technical University of Munich
\end{tabular}

${ }^{1}$ Note: Unless otherwise noted, cited references in all workshop abstracts can be found in the "Bibliography for In-Situ Production Rates" following this Overview.

${ }^{2}$ Geology and Geochemistry Group, EES-1, MS D462

${ }^{3}$ Astrophysics and Radiation Measurements Group, NIS-2, MS D436

${ }^{4}$ Geology and Geochemistry Group, EES-1, MS D462

${ }^{5}$ Chemical Science and Technology, CST-7, MS J514 


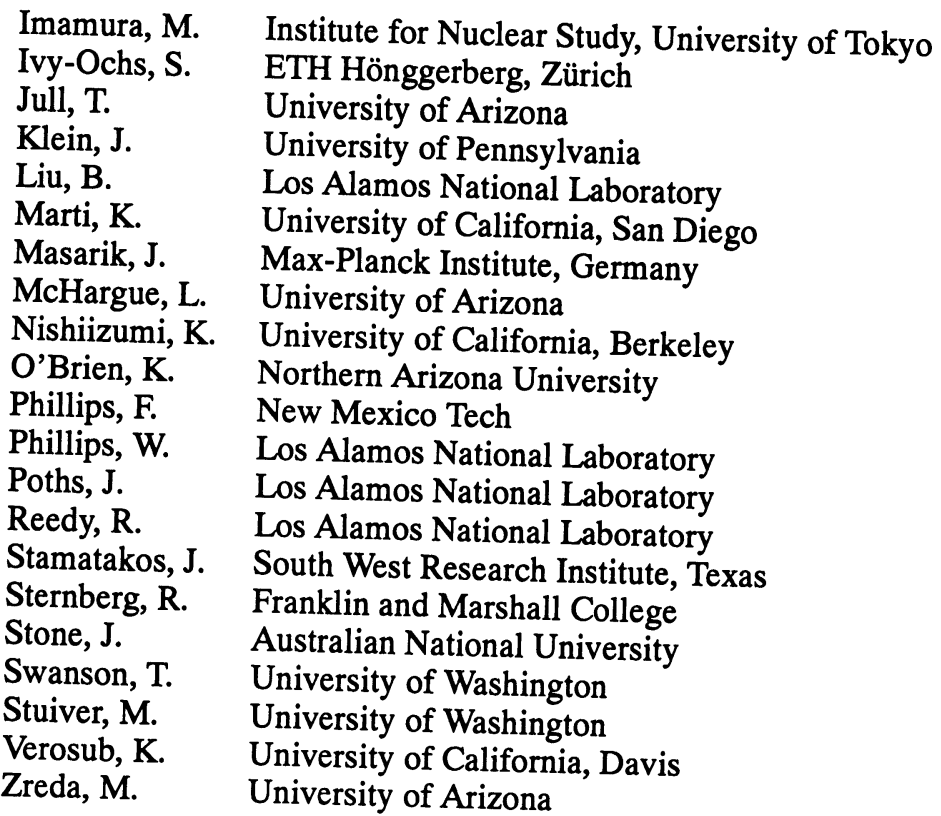

The group recognized the limits and various sources of systematic uncertainties of the cosmogenic nuclides methods, especially the many ancillary data sets used, such as those used in adjustments for elevation and geomagnetic effects. There was a unique opportunity for open discussion and evaluation of the geological and chronological assumptions for the major calibration sites. Input from the fields of paleomagnetism, radiocarbon dating and cosmic-ray physics helped to address questions as
they arose.

\section{Workshop Goals}

The following goals and questions were addressed during the workshop:

1. To discuss the measurement of in-situ cosmogenic nuclide production rates. How accurate are the current measurements? How accurate do we need them to be and what are the limitations? How well do we know the relative production rates of cosmogenic nuclides? What should be involved in selection of calibration sites? What factors are important to consider? What are some suggestions for good calibration sites? What are the caveats involved in measuring production rates at calibration sites and what experiences can be shared to decrease the probability of repeating mistakes?

2. To discuss models relating cosmic-ray intensity and nuclear cross sections to production rates. What do the models tell us about spatial variability? What can they tell us about temporal variations? How good are the models? For example, if we accurately knew the Earth's magnetic dipole paleointensity, how accurately can we now calculate production rates on Earth? What What is needed to improve the mels and their magnitudes? Are these models worth pursuing?

3. To summarize the improve the models? How strongly are cross section measurements needed? production rates current state of knowledge concerning temporal and spatial variability of exists? What noeds well do we know the spatial and temporal dependencies? What literature latitude? Where shou be done to improve our knowledge of the dependencies on altitude and for very low and very high latitudents of in-situ production rates be focused? What is the need 
4. To discuss surrogate records of changes in parameters that affect production rates. What records can be used now? How good are they? What improvements are being attempted that will have an impact on production rate modeling within the next half decade? What models exist or are needed to calculate changes in production rates based on changes in such factors as the strength of the Earth's magnetic field? What records of prehistoric solar activity are available and how good are they?

5. To make suggestions that will help direct future efforts to calibrate cosmogenic nuclide surface exposure dating methods.

6. To compile a bibliography of current relevant publications (see below).

\section{State of Production Rate Knowledge}

The talks and discussions covered a wide range of topics and data. The reader is referred to the abstracts and bibliography to attain the most recent estimates of production rates. Estimates of the in-situ production rates of the cosmogenic nuclides currently used in exposure history applications were presented and evaluated at the workshop. Production rate estimates have been determined from measurements of the nuclides in geologic samples and artificial samples (such as water) and through numerical simulations of the reactions involved. It is clear that the uncertainty of a production rate for a given sample site is improving with the increasing number of empirically and experimentally derived production rates.

However, some important discrepancies are evident in the existing production rate estimates. The reasons for the discrepancies are complicated because multiple variables are involved, including 1) the calibration sites may have had uncertain exposure histories, e.g., some sites may have been partially buried by till, snow, or ejecta; 2 ) there are inherent uncertainties in the calibration age for the site, due to either assumptions associated with the calibration age or the geomorphic relationship between the site for the calibration age and that for the cosmogenic nuclide sample ( $c f$. abstract of Clark et al.); 3) the calibrations were done for different exposure durations and geographic locations-variations in the Earth's geomagnetic field strength with time and location can account for significant variability on a $20 \mathrm{kyr}$ timescale and; 4) the uncertainties associated with the scaling that is used to normalize production rates to sea level and high latitude can cause additional deviations. It was generally agreed that multiple sites of calibration are needed to provide information and constraints on elevation, latitude and temporal controls on production rates. The need for cross calibration of the production rates of different cosmogenic nuclides was also emphasized.

New and previous empirical data, used to calculate or verify production rates for ${ }^{10} \mathrm{Be}$ and ${ }^{26} \mathrm{Al}$ in quartz, were presented by Nishiizumi et al., Bierman et al., Gosse and Klein, Ivy-Ochs et al., Brown et al. and Brook et al. The rates normalized for production at sea level and high latitude are in fairly close agreement (all were within $5.6 \pm 0.5$ atoms $\cdot \mathrm{g}^{-1} \cdot \mathrm{yr}^{-1}$ ) for times ranging from the present to $>10 \mathrm{Myr}$.

The rates for in-situ ${ }^{14} \mathrm{C}$ in quartz were reported by Jull and $\mathrm{McHargue}$. The use of in-situ ${ }^{14} \mathrm{C}$ work is relatively recent and more production rate measurements are immediately needed. Considering the importance of ${ }^{14} \mathrm{C}$ in erosion rate and burial studies due to its short half-life, production rate refinement for this nuclide should get considerably more attention.

Data useful in constraining production rates of the cosmogenic noble gases ${ }^{3} \mathrm{He}$ and ${ }^{21} \mathrm{Ne}$ were presented by Brook et al., Brown et al., Poths et al., Phillips, W. et al. and Marti and Graf. The current production rate estimates of these nuclides are in reasonable agreement for times $>10 \mathrm{kyr}$. Discussions concerning the diffusion of the gases, such as ${ }^{3} \mathrm{He}$ in quartz and the non-cosmogenic compo- 
nents of the elements, addressed the present state of understanding and made suggestions for future noble gas experiments. Although M. Kurz and T. Cerling were unable to attend, references to their work in noble gas production rates are included in the bibliography.

Estimates of production rates of ${ }^{36} \mathrm{Cl}$ from various pathways (thermal neutron capture, muonic reactions and spallation reactions) were presented by F. Phillips et al., Swanson et al. and Stone et al. The production rate estimates varied considerably, partly due to the factors mentioned above and partly due to the complications involved in the interactions of multiple cosmogenic and non-cosmogenic production pathways. Nevertheless, the production rates of ${ }^{36} \mathrm{Cl}$ are now sufficiently well known to yield ages that are within reasonably close agreement to ages calculated with cosmogenic ${ }^{10} \mathrm{Be}$ and ${ }^{26} \mathrm{Al}$, based on data presented by Ivy-Ochs et al., Gosse and Klein and Phillips, F. et al. This agreement is encouraging for our knowledge of the relative production rates of each nuclide.

Results of ongoing numerical simulations to calculate the production of various nuclides from different targets and at different energies was presented by O'Brien, Reedy and Masarik and Reedy. Production rates from the simulations show very good agreement with some measured production rates. Uncertainties in the fluxes of cosmic-ray particles (especially neutrons and muons), uncertainties in the reaction cross sections with various target elements and other sources of error were recognized when the simulation data were evaluated. Imamura reported on measurements of cross sections for producing these nuclides by energetic neutrons. Heisinger $e$ t al. presented work using accelerator-produced stopped negative muons and fast muons and comparisons with a measured depth profile to $250 \mathrm{~m}$. A discrepancy between the contribution of muons that some models predict and the contribution that has been previously assumed (the assumed contribution may be too high) provided insight into the importance of the muonic reactions.

\section{Other Lessons Learned}

Much discussion centered on the effects of solar and Earth magnetic influences on the incident cosmic ray flux. There is a well-understood relationship between incident cosmic ray flux and the dipole moment of the Earth. Instantaneous in-situ cosmogenic nuclide production rates in rocks on Earth vary in a way similar to how production rates of the ${ }^{14} \mathrm{C}$ in the atmosphere varies: during periods of low field intensity, production rate is high and vice versa. The main difference is that the concentration of in-situ nuclides is the integral of the production rates over the entire exposure period whereas ${ }^{14} \mathrm{C}$ ratios record the production rate at small instances of time. Although short-lived highamplitude changes in paleointensity will affect the atmospheric ${ }^{14} \mathrm{C}$ time scale, the cosmogenic nuclide time scale will not feel the effects of a short paleointensity change unless the exposure time is of similar duration.

Several programs are being generated (Clapp et al.: COSMO-CALIBRATE; Dunne et al.) to correct cosmogenic nuclide production rates due to changes in the intensity of Earth's dipole field strength. These programs are useful to show the sensitivity of the integrated production rates of cosmogenic nuclides to changes in the geomagnetic field-however, they are only as good as the input data (see below). Using the existing paleointensity records, the programs predict that, depending on the latitude and elevation of the site, the time-integrated production rate for an exposure over the last $40 \mathrm{kyr}$ is much higher (possibly $20 \%$ ) than the production rate over the last $5 \mathrm{kyr}$.

Unfortunately, existing absolute and relative paleointensity records are not sufficiently reliable to base adjustments of cosmogenic nuclide production rates. A presentation by $K$. Verosub and the ensuing discussions revealed the difficulties that paleomagnetists have had in interpreting the paleomagnetic data. Sources of uncertainties in the paleointensity records include poor age control, dif- 
ficulty in evaluating the significance of non-dipole contributions and errors due to variations in magnetic grain size, multi-domain remanences and inclination shallowing. The uncertainty of many of the existing paleointensity records therefore probably approaches or exceeds $20 \%$. Until more paleointensity records become available it may be difficult to adjust cosmogenic nuclide production rates with high degrees of uncertainty.

Other sources of variation in production rates were discussed at the workshop. R. Sternberg showed that significant changes in the average geomagnetic latitude of sampled sites (up to $4^{\circ}$ over exposure durations longer than $2 \mathrm{kyr}$ ) are caused by secular variation of the dipole axis position. Only sites $<\sim 15 \mathrm{kyr}$ are affected because the dipole axis position is approximately geocentric for longer exposures. The effects of a $2-4^{\circ}$ uncertainty in geomagnetic latitude were modeled by Klein and Gosse, who showed that for high altitude mid-latitude sites $\left(\sim 30^{\circ}\right.$ latitude) the uncertainty could cause a discrepancy in production rate on the order of $10 \%$.

The influence of solar modulation over a solar cycle was discussed by K. O'Brien. The model results he presented and results from simulation efforts by R. Reedy and J. Masarik suggest that solar modulation may play a significant role at high latitudes.

The uncertainty in the protocol for scaling production rates to different latitudes and altitudes was the theme of many discussions throughout the workshop. Existing data seem to suggest that the altitudinal correction of $\mathrm{Lal}(1991)$ is reliable to within $10 \%$. However, J. Stone pointed out that elevation corrections may be complicated because atmospheric thickness above any site may change significantly due to a combination of factors such as eustatic sea level changes and glacial isostacy. Also, some special cases exist such as the effects on atmospheric thickness of the quasi-stable low atmospheric pressure and cold air over Antarctica. There was considerable disagreement on the reliability of the Lal (1991) latitudinal scaling. The debate over the relative significance of muon effects on latitude and altitude adjustments is not fully resolved. The effects of non-dipole field variations are presently ignored, mostly because insufficient data are available to model Quaternary non-dipole field paleointensities over the globe, according to J. Stamatakos. However, the spatial and temporal variations in non-dipole field strengths may be significant for Holocene measurements. I. Graham reported on plans that his group is making to measure production rates over a wide range of latitudes.

Discussions on the reliability of the dating methods against which the in-situ nuclide time scales are being calibrated centered on the ${ }^{14} \mathrm{C}$ method, and to a lesser extent, the ${ }^{40} \mathrm{Ar} /{ }^{39} \mathrm{Ar}$ technique. The utility of surfaces assumed to be in saturation for ${ }^{10} \mathrm{Be}$ and ${ }^{26} \mathrm{Al}$ in Antarctica (and the reliability of the ${ }^{10} \mathrm{Be}$ and ${ }^{26} \mathrm{Al}$ half-lives) was also discussed. The majority of the production rate calibrations have been at $<20 \mathrm{kyr}$, based on ${ }^{14} \mathrm{C}$ ages. The calibrated ${ }^{14} \mathrm{C}$ time for ages $<\sim 11 \mathrm{kyr}$ is generally believed to be sufficiently reliable for calibration. Disagreement over the reliability of the U/Th coral calibration of older ${ }^{14} \mathrm{C}$ ages (to $\sim 18 \mathrm{kyr}$ ) was not completely resolved, although $\mathrm{M}$. Stuiver presented convincing isotopic data from the GISP core which supported the extended ${ }^{14} \mathrm{C}$ calibration curve. It is clear that continued improvement in calibration of the ${ }^{14} \mathrm{C}$ time scale is needed. Refinements in long term in-situ production rates will continue as improvements in the understanding of latitude and altitude effects enable reliable extrapolation of Antarctic production rates to other locations and by cautiously taking advantage of recent advances in Ar-Ar dating of whole rocks. 


\section{Suggestions for Future Calibration of Cosmogenic Nuclide Time Scales}

The following points reached general consensus among the group:

1. If possible, calibration against ages derived from other calibrated dating methods or other cosmogenic nuclide ages should be avoided. It was suggested that more emphasis should be placed on calibrating with ages based on the $U$ and Ar systems.

2. It was pointed out that several existing production rates may be slightly low because the age assumed for the exposure duration was too high due to shielding by till or sediment (e.g., rocks at Meteor Crater may have been covered by ejecta). When selecting a site for calibration, the potential for partial or complete shielding due to burial must be considered. For young sites $(<20$ $\mathrm{kyr}$ ) the effects of erosion are probably insignificant when compared to the effects of burial. For example, selection of sites with glacial polish to ensure no erosion has occurred since deglaciation may be counter-productive if the reason the polish has survived is because it was protected by a soil cover.

3. The group recommended that because suitable calibration sites are so difficult to find, no specific site latitude, elevation, or exposure duration should be particularly targeted.

4. It was also agreed that future proposed calibration sites should be peer evaluated so that any merits and problems of the site can be identified before the production rate data is generated. No official forum was suggested because it was felt that informal discussion should be sufficient.

5. An attempt should be made to measure multiple nuclides at calibration sites where funding and mineralogy/lithology permit. Also, multiple samples should be analyzed for at least one nuclide at each site to help minimize the effects of erosion, burial and pre-exposure.

Participants of the workshop have also agreed to conduct an inter-laboratory comparison of various aspects of the chemistry and isotopic measurements involved in the cosmogenic nuclide methods. Wide interest was expressed in an inter-laboratory standard, with one suggestion being Tabernacle Hill, Utah, where multiple lithologies co-exist with tight age constraints.

\section{Suggestions for Future Authors or Reviewers of Publications Containing Interpretations of Cosmogenic Nuclides}

In order to calculate exposure ages or erosion rate information from the measured cosmogenic isotopic abundances, numerous other measurements and data must be considered and incorporated. The protocol is generally straightforward but can be rather involved. Representatives of several of the laboratories where measurements of the abundances of the cosmogenic nuclides are made have pointed out that cosmogenic nuclide dating is beginning to be carried out by scientists who have not been involved in the technique development over the last decade. We can only recommend that the researcher considers the question being addressed before selecting the nuclide systems being utilized and that before collecting the sample, the researcher makes himself aware of all of the caveats and information needed. Once an erroneous age makes it into the literature it is sometimes very difficult to remove it.

There are several reasons why a single production rate for a particular nuclide cannot be suggested. The production rate for any nuclide at any time and location is not well known, mostly because of the very limited data set that exists but also because of small but significant discrepancies in the production rates that have been measured. Additionally, because the production rates probably change due to temporal fluctuations in the effective cosmic ray flux to the rock surface (due to past variations in geomagnetic field strength, dipole axis position, solar modulation, atmospheric pressure and 
other factors), a single time-independent production rate is not viable. Finally, there remain uncertainties in the scaling of production rates over different altitudes and latitudes.

Other factors that must be considered when calculating a site production rate based on the effective cosmic ray flux a rock receives includes the rock sample thickness and depth below the surface, surface geometry (addressed by A. Gillespie), amount of shielding of cosmic radiation (e.g., by snow, water, sediment and topography with respect to the horizon) and erosion rate and style.

It is therefore crucial that authors consider including the following information so that as the science continues to develop we can re-evaluate the interpretations of the cosmogenic nuclide data (e.g., just as the calibration of the ${ }^{14} \mathrm{C}$ timescale is continually being improved). If page length restrictions limit the ability of the incorporation of these data, then the data should be made accessible elsewhere and that source be furnished. The list is not exhaustive but we hope reviewers of manuscripts will adhere to the suggestions (Table 1). Some other data may be necessary, depending on the technique and detailed descriptions of geometry and shielding should be included if applicable.

Meaningful estimates of the uncertainties in all calculated ages and erosion rates should be provided. Because the level of confidence or types of uncertainties used to describe the error limits may vary due to nature of the data or the style of the author, we recommend that some indication of what the error limit calculation involves also be included.

TABLE 1. Information Suggested to Accompany Published Data

\begin{tabular}{|c|c|}
\hline Data/parameter & Suggested unit or means \\
\hline Site latitude and longitude & $\circ$ \\
\hline Site elevation & $\mathrm{m}$ \\
\hline Effective attenuation length & $\mathrm{g} \cdot \mathrm{cm}^{-2}$ \\
\hline Density of the rock sampled & $\mathrm{g} \cdot \mathrm{cm}^{-3}$ \\
\hline Production rate(s) used & Atom $\cdot \mathrm{yr}^{-1} \cdot \mathrm{g}^{-1}$ of material \\
\hline $\begin{array}{l}\text { Thickness/depth of the sample } \\
\text { Chemical data }\end{array}$ & $\mathrm{cm}$ \\
\hline $\begin{array}{l}\text { Isotopic data } \\
\text { Geometry/slope correction applied*, } \dagger\end{array}$ & $\begin{array}{l}\text { Atom } \cdot \mathrm{g}^{-1} \text { of material, or equivalent } \\
\text { Dimensionless }\end{array}$ \\
\hline $\begin{array}{l}\text { Geometry/slope correction applied*, } \dagger \\
\text { Shielding correction applied* }, \dagger\end{array}$ & $\begin{array}{l}\text { Dimensionless } \\
\text { Dimensionless }\end{array}$ \\
\hline Density of the covering material* & $\mathrm{g} \cdot \mathrm{cm}^{-3}$ \\
\hline Thickness of the shielding cover*,$\dagger$ & $\mathrm{cm}$ \\
\hline Duration of cover if known* & yr or kyr \\
\hline Erosion rate correction $*, \uparrow$ & Dimensionless, or $\mathrm{mm} \cdot \mathrm{kyr}^{-1}$ or equivalent \\
\hline Latitude and altitude scaling factor ${ }^{*}, \dagger$ & Dimensionless; provide ref. (e.g., Lal 1991) \\
\hline
\end{tabular}

*If applicable
†Requires explanation

\section{Utility of Cosmogenic Nuclide Exposure History Techniques}

This workshop focused on how to improve our understanding of cosmogenic nuclide production rates and make recommendations for future calibrations. However, many unresolved questions involving Neogene chronologies, landform stability and tectonic, seismic, volcanic and climatic issues can be addressed with sufficient accuracy with the present uncertainty in the rates of production of cosmogenic nuclides. Some examples include 1) estimates of erosion rates to within $20 \%$ is generally of sufficient accuracy to address landform- or basin-scale questions; 2) relative sequences of events such as detailed deglaciation patterns or fan deposition can be attained from cosmogenic 
nuclides because the precision of the techniques approaches 3 to $5 \%$; 3) similarly, cosmogenic nuclides can be used for correlation purposes (e.g., the existence of Younger Dryas moraines around the world) by comparing normalized concentrations $( \pm 10 \%)$ of the same nuclide, thereby avoiding calibration to a different time scale; and 4) chronologic questions that do not require highly accurate exposure age assignments (better than 15\%), such as 1) was this colluvial deposit formed during the early Quaternary, middle Quaternary or Late Quaternary, or 2) does this moraine correspond to a marine oxygen isotope stage II or an older ice volume advance?

Although many questions can be addressed with the existing uncertainties in production rates, it is clear that better estimates of production rates are direly needed to utilize the cosmogenic nuclide techniques to their full potential. A number of challenging questions that directly impact society will remain largely unanswered until the cosmogenic nuclide methods evolve further over the next decade.

\section{ACKNOWLEDGMENTS}

The workshop was sponsored by: National Science Foundation EAR-9526774; Office of Basic Energy Sciences-Geosciences and Engineering; Los Alamos National Laboratory: Earth and Environmental Sciences Division, Chemical Science and Technology Division, Institute of Geophysics and Planetary Physics and the Los Alamos National Laboratory Yucca Mountain Program Office. We thank Kim Thompson, Anthony Garcia, Lanny Piotrowski, Phyllis Auchampaugh, Carol LaDelfe, Grant Heiken, Scott Baldrich and Jim Aldrich for support and suggestions.

\section{BIBLIOGRAPHY FOR IN-SITU PRODUCTION RATES}

Anthony, E. Y., McIntosh, W. C., Poths, J., Williams, W. J. W., Whitelaw, M. and Geissman, J. 1994 Geochronology and paleomagnetism of the Quaternary Potrillo volcanic field, Rio Grande Rift, New Mexico: Abstracts of the 8th International Conference on Geochronology, Cosmochronology and Isotope Geology. USGS Circular 1107: 10.

Bard, E., Hamelin, B., Fairbanks, R. G. and Zindler, A. 1990 Calibration of the ${ }^{14} \mathrm{C}$ timescale over the past 30,000 years using mass spectrometric U-Th ages from Barbados corals. Nature 345: 405-410.

Bard, E., Hamelin, B., Fairbanks, R. G., Zindler, A., Mathieu, G. and Arnold, M. 1990 U/Th and ${ }^{14} \mathrm{C}$ ages of corals from Barbados and their use for calibrating the ${ }^{14} \mathrm{C}$ time scale beyond 9000 years BP. Nuclear Instruments and Methods in Physics Research B52: 461-468.

Baros, F. and Regnier, S. 1984 Measurement of cross sections for ${ }^{22} \mathrm{Ne},{ }^{20-22} \mathrm{Ne}$ and ${ }^{36-42} \mathrm{Ar}$ in the spallation of $\mathrm{Mg}, \mathrm{Al}, \mathrm{Si}, \mathrm{Ca}$ and $\mathrm{Fe}$ : Production ratios of some cosmogenic nuclides in meteorites. Journal de Physique 45: 855-861.

Becker, B. 1993 An 11,000-year German Oak and Pine dendrochronology for radiocarbon calibration. In Stuiver, M., Long, A. and Kra, R. S., eds., Calibration 1993. Radiocarbon 35(3): 201-213.

Beer, J. Andree, M., Oeschger, H., Siegenthaler, U., Bonani, G., Hofmann, H., Morenzoni, E., Nessi, M., Suter, M., Wölfli, W., Finkel, R. and Langway, C.
1984 The Camp Century ${ }^{10} \mathrm{Be}$ record: Implications for long-term variations of the geomagnetic dipole moment. Nuclear Instruments and Methods in Physics Research B5: 380-384.

Beer, J. et al. 1983 Temporal ${ }^{10} \mathrm{Be}$ variations: Proceedings of the 18th International Cosmic Ray Conference, Bangalore 9: 317-320.

1983 Temporal ${ }^{10} \mathrm{Be}$ variations in ice. In Stuiver, $\mathrm{M}$. and Kra, R. S., eds., Proceedings of the 11 th International ${ }^{14} \mathrm{C}$ Conference. Radiocarbon 25(2) 269-278.

Beer, J., Siegenthaler, U., Bonani, G., Finkel, R. C., Oeschger, H., Suter, M. and Wölfli, W. 1988 Information on past solar activity and geomagnetism from ${ }^{10} \mathrm{Be}$ in the Camp Century ice core. Nature 331: 675-679.

Bierman, P. R., Gillespie, A. R. and Caffee, M. W. 1995 Cosmogenic ages for earthquake recurrence intervals and debris flow for deposition, Owens Valley, California. Science 270(5235): 447-450.

Brook, E. J., Brown, E. T., Kurz, M. D., Ackert, R. P., Raisbeck, G. M. and Yiou, F. 1995 Constraints on erosion and uplift rates of Pliocene glacial deposits in the Transantarctic Mountains using in situ-produced ${ }^{10} \mathrm{Be}$ and ${ }^{26} \mathrm{Al}$. Geology 23: 1063-1068

Brook, E. J. and Kurz, M. D. 1993 Using in situ cosmogenic ${ }^{3} \mathrm{He}$ in Antarctic quartz sandstone boulders for surface-exposure chronology. Quaternary Research 39: 1-10.

Brown, E. T., Bourles, D. L., Colin, F., Raisbeck, G. M., Yiou, F. and Desgarceaux, S. 1995 Evidence for 
muon-induced in situ production of ${ }^{10} \mathrm{Be}$ in near-surface rocks from the Congo. Geophysical Research Letters 22: 703-706.

Brown, E. T., Brook, E. J., Raisbeck, G. M., Yiou, F. and Kurz, M. D. 1992 Effective attenuation lengths of cosmic rays producing ${ }^{10} \mathrm{Be}$ and ${ }^{26} \mathrm{Al}$ in quartz: Implications for exposure age dating. Geophysical Research Letters 19: 369-372.

Brown, E. T. et al. 1991 Examination of surface exposure ages of Antarctic moraines using in situ produced ${ }^{10} \mathrm{Be}$ and ${ }^{26} \mathrm{Al}$. Geochimica et Cosmochimica Acta 55: 2269-2283.

Castagnoli, G. and Lal, D. 1980 Solar modulation effects in terrestrial production of Carbon-14. In Stuiver, M. and Kra, R. S., eds., Proceedings of the 10th International ${ }^{14} \mathrm{C}$ Conference. Radiocarbon 22(2): 133-158.

Cerling, T. E. 1990 Dating geomorphologic surfaces using cosmogenic ${ }^{3} \mathrm{He}$. Quaternary Research 33: 148-156.

Cerling, T. E. and Craig, H. 1994 Cosmogenic ${ }^{3} \mathrm{He}$ production rates from $39^{\circ} \mathrm{N}$ to $46^{\circ} \mathrm{N}$ latitude, western USA and France. Geochimica et Cosmochimica Acta 58: 249-255.

Clapp, E. and Bierman, P. 1995 First geomagnetic-based, in situ produced cosmogenic isotope calibration program. Geological Society of America Abstracts with Programs 27: A59.

Clapp, E. and Bierman, P. (ms.) COSMO-CALIBRATE: A program for calibrating cosmogenic exposure ages. Submitted to Geophysical Research Letters.

Clark, D. H., Bierman, P. R. and Larsen, P. 1995 Improving in situ cosmogenic chronometers. Quaternary Research 44: 366-376.

Clark, D. H. and Gillespie, A. R., in press, Timing and significance of late-glacial and Holocene glaciation in the Sierra Nevada, California. Quaternary International.

Cui, Y. and Verosub, K. L. 1995 A mineral magnetic study of some pottery samples: Possible implication for sample selection in archaeointensity studies. Physics of the Earth and Planetary Interiors 91: 261-271.

Damon, P. E. and Linick, T. W. 1986 Geomagnetic-heliomagnetic modulation of atmospheric radiocarbon production. In Stuiver, M. and Kra, R. S., eds. Proceedings of the 12 th International ${ }^{14} \mathrm{C}$ Conference. Radiocarbon 28(2A): 266-278.

Dep, L. 1995 (ms.) Cosmogenic radionuclide production in terrestrial rocks: Accelerator mass spectrometry measurements and Monte Carlo simulations. Ph.D. dissertation, Purdue University.

Dep, L., Elmore, D., Fabryka-Martin, J., Masarik, J. and Reedy, R. C. 1994a Numerical simulation of cosmogenic nuclide production in rocks for various exposure geometries. Abstracts of the 8th International Conference on Geochronology, Cosmochronology and Isotope Geology. USGS Circular 1107: 80.

1994b Production rate systematics of cosmogenic nuclides in terrestrial rocks using Monte-Carlo meth- ods. Nuclear Instruments and Methods B92: 321-325.

Dockhorn, B., Neumaier, S., Hartmann, F. J., Petitjean,

C., Faestermann, H. and Nolte, E. 1991 Determination of erosion rates with cosmic ray produced ${ }^{36} \mathrm{Cl}$. Zeitschrift Physik A341: 117-119.

Elsasser, W., Ney, E. P. and Winckler, J. R. 1956 Cosmicray intensity and geomagnetism. Nature 178: 12261227.

Finkel, R. and Suter, M. 1993 AMS in the Earth Sciences: Technique and applications. Advances in Analytical Geochemistry 1: 1-114.

Florek, M., Masarik, J., Szarka, I., Nikodemova, D. and Hrabovcova, H. (ms.) Natural neutron fluence and the equivalent dose in localities with different altitudes, radiation protection. Submitted to Radiation Protection.

Foukal, P. and Lean, J. 1990 An empirical model of total solar irridiance variation between 1874 and 1988. Science 247: 556-558.

Gosse, J. C., Evenson, E. B., Klein, J., Lawn, B. and Middleton, R. 1995 Precise cosmogenic ${ }^{10} \mathrm{Be}$ measurements in western North America: Support for a global Younger Dryas cooling event. Geology 23: 877-880.

Gosse, J. C., Klein, J. and Harrington, C. 1996 Intricacies in calibrating the cosmic-ray exposure time scale. American Association for the Advancement of Science Annual Meeting, Baltimore Abstracts and Program, 8-13 February: A38.

Graf, T., Kim, J. S., Marti, K. and Niedermann, S. 1995 Cosmic-Ray-Produced Neon at the Surface of the Earth. In Noble Gas Geochemistry and Cosmochemistry. Tokyo, Terra Scientific Publishing Company: 115-123.

Graf, T., Kohl, C. P., Marti, K. and Nishiizumi, K. 1991 Cosmic-ray produced neon in Antarctic rocks. Geophysical Research Letters 18: 203-206.

Gubbins, D. and Kelly, P. 1993 Persistent patterns in the geomagnetic field over the past $2.5 \mathrm{Myr}$. Nature 365: 829-832.

1995 On the analysis of paleomagnetic secular variation. Journal of Geophysical Research 100: 1495514964.

Hampel, W., Takagi, J., Sakamoto, K. and Tanaka, S. 1975 Measurement of muon-induced ${ }^{26} \mathrm{Al}$ in terrestrial silicate rock. Journal of Geophysical Research 80: 3757-3760.

Hanna, R. L. and Verosub, K. L. 1989 A review of lacustrine paleomagnetic records from western North America: 0-40,000 years BP. Physics of the Earth and Planetary Interiors 56: 76-95.

Hashizume, K. and Sugiura, N. 1992 Measurement of cosmogenic nitrogen using a static mass-spectrometry system and its implication. Geochimica et Cosmochimica Acta 56: 1625-1631.

Heinrich, W. and Spill, A. 1979 Geomagnetic shielding of cosmic rays for different satellite orbits. Journal of Geophysical Research 84: 4401.

Hollerbach, R. and Jones, C. A. 1993 Influence of the 
Earth's inner core on geomagnetic fluctuations and reversals. Nature 365: 541-543.

Hudson, G. B., Caffee, M. W., Beiringer, J., Ruiz, B., Kohl, C. P. and Nishiizumi, K. 1991 Production rate and retention properties of cosmogenic ${ }^{3} \mathrm{He}$ and ${ }^{21} \mathrm{Ne}$ in quartz. EOS 72: 575.

Imamura, M., Kobayashi, K., Nagai, H., Sugita, H., Nakamura, T., Shibata, S. and Uwamino, Y. 1991 Application of Accelerator Mass Spectrometry at the Tandem Facility of University of Tokyo-Measurement of neutron- and photon-induced reaction cross sections. Proceedings of the 2nd International Symposium on Advanced Nuclear Energy Research-Evolution by Accelerators, v. Mito, Japan 1990: 602-607 (Note: error exists in the ${ }^{27} A l(n, 2 n)^{26} A l$ cross section data in this paper; all data must be divided by 1.6).

Imamura, M., Nagai, H., Takabatake, M., Shibata, S., Kobayashi, K., Yoshida, K., Ohashi, H., Uwamino, Y. and Nakamura, T. 1990 Measurements of production cross sections of ${ }^{14} \mathrm{C}$ and ${ }^{26} \mathrm{Al}$ with high energy neutrons up to $\mathrm{E}_{\mathrm{n}}=38 \mathrm{MeV}$ by Accelerator Mass Spectrometry. Nuclear Instruments and Methods in Physics Research B52: 595-600.

Ivy-Ochs, S., Schlüchter, C., Kubik, P. W. and Beer, J. 1995 Surface exposure dating of a Younger Dryas moraine in the Swiss Alps using ${ }^{10} \mathrm{Be}$ and ${ }^{26} \mathrm{Al}$. Paul Scherrer Institut, ETH Annual Report 1993/1994 Ion Beam Physics: 47.

Ivy-Ochs, S., Schlüchter, C., Kubik, P. W., Bruno, L., Masarik, J. and Beer, J. (ms.) The usefulness of pyroxene for ${ }^{10} \mathrm{Be}$ exposure dating: A comparison of sequential leaching of quartz and pyroxene. Submitted to Earth and Planetary Science Letters.

Jull, A. J. T., Donahue, D. J., Linick, T. W. and Wilson, G. C. 1989 Spallogenic ${ }^{14} \mathrm{C}$ in high-altitude rocks and Antarctic meteorites. In Long, A., Kra, R. S. and Srdo丈, D., eds., Proceedings of the 13 th International ${ }^{14} \mathrm{C}$ Conference. Radiocarbon 31(3): 719-724.

Jull, A. J. T., Lal, D., Donahue, D. J., Mayewski, P., Lorius, C., Raynaud, D. and Petit, J. R. 1994 Measurements of cosmic-ray-produced ${ }^{14} \mathrm{C}$ in firn and ice from Antartica. Nuclear Instruments and Methods B92: 326-330.

Jull, A. J. T., Lifton, N., Phillips, W. M. and Quade, J. 1994 Studies of the production rate of cosmic-ray produced ${ }^{14} \mathrm{C}$ in rock surfaces. Nuclear Instruments and Methods in Physics Research B92: 308-310.

Jull, A. J. T., Wilson, A. E., Burr, G. S., Toolin, L. J. and Donahue, D. J. 1992 Measurements of cosmogenic ${ }^{14} \mathrm{C}$ produced by spallation in high-altitude rocks. In Long, A. and Kra, R. S., eds., Proceedings of the 14th International ${ }^{14} \mathrm{C}$ Conference. Radiocarbon 34(3): 737-744.

King, J. W., Banerjee, S. K. and Marvin, J. 1983 A new rock-magnetic approach to selecting sediments for geomagnetic paleointensity studies: Application to paleointensity for the last 4000 years. Journal of Geo- physical Research 88: 5911-5921.

Kromer, B. and Becker, B. 1990 Tree-ring ${ }^{14} \mathrm{C}$ calibration at 10,000 BP. In Bard, E. and Broecker, W. S., eds., The Last Deglaciation: Absolute and Radiocarbon Chronologies, NATO ASI Series I, Vol. 2. Berlin, Springer-Verlag: 3-11.

Kurz, M. 1986 In situ production of terrestrial cosmogenic helium and some applications to geochronology. Geochimica et Cosmochimica Acta 50: 28552862.

Kurz, M., Colodner, D., Trull, T. W. and Sampson, D. E. 1987 Exposure age dating with cosmogenic ${ }^{3} \mathrm{He}: \mathrm{In}-$ fluence of the Earth's magnetic field: EOS 68: 1286.

Kurz, M. D. 1986 Cosmogenic helium in a terrestrial igneous rock. Nature 320: 435-439.

Kurz, M. D., Colodner, D., Trull, T. W., Moore, R. B. and O'Brien, K. 1990 Cosmic ray exposure dating with in situ produced cosmogenic ${ }^{3} \mathrm{He}$ : Results from young Hawaiian lava flows. Earth and Planetary Sciences 97: 177-189.

Lal, D. 1987 Cosmogenic nuclides produced in situ in terrestrial solids. Nuclear Instruments and Methods in Physics Research B29: 238-245.

1987 Production of ${ }^{3} \mathrm{He}$ in terrestrial rocks. Chemical Geology 66: 89-98.

1991 Cosmic ray labeling of erosion surfaces: In situ nuclide production rates and erosion rates. Earth and Planetary Science Letters 104: 424-439.

Lal, D., Arnold, J. R. and Nishiizumi, K. 1985 Geophysical records of a tree: New application for studying geomagnetic field and solar activity changes during the past $10^{4}$ years. Meteoritics 20: 403-414.

Lal, D. and Jull, A. J. T. 1990 On determination of ice accumulation rates in the past 40,000 years using in-situ cosmogenic ${ }^{14} \mathrm{C}$. Geophysical Research Letters 17: 1303-1306.

1992 Cosmogenic nuclides in ice sheets. Radiocarbon 34(2): 227-233.

Lal, D., Jull, A. J. T., Burtner, D. and Nishiizumi, K. 1990 Polar ice ablation rates measured using in-situ cosmogenic ${ }^{14} \mathrm{C}$. Nature 346: 350-352.

Lal, D., Nishiizumi, K., Reedy, R. C., Suter, M. and Wölfli, W. 1987 An accurate measurement of the ${ }^{10} \mathrm{~B}(\mathrm{n}, \mathrm{p}){ }^{10} \mathrm{Be}$ cross section at thermal energies. $\mathrm{Nu}$ clear Physics A468: 189-192.

Lal, D. and Peters, B. 1967 Cosmic-ray produced radioactivity on the Earth. Handbook of Physics, Volume 46/2. Berlin, Springer-Verlag: 551-612.

Lao, Y., Anderson, R. F., Broecker, W. S., Trumbore, S. E., Hofmann, H. F. and Wölfli, W. 1992 Increased production of cosmogenic ${ }^{10} \mathrm{Be}$ during the Last Glacial Maximum. Nature 357: 576-578.

Larsen, P. 1995 (ms.) In situ production rates of cosmogenic ${ }^{10} \mathrm{Be}$ and ${ }^{26} \mathrm{Al}$ over the past $21.5 \mathrm{ky}$ from the terminal moraine of the Laurentide ice sheet, north central New Jersey. Master's thesis, University of Vermont. 
Larsen, P. L., Bierman, P. R. and Caffee, M. 1995 Preliminary in situ production rates of cosmogenic ${ }^{10} \mathrm{Be}$ and ${ }^{26} \mathrm{Al}$ over the past $21.5 \mathrm{ky}$ from the terminal moraine of the Laurentide ice sheet, north-central New Jersey. Geological Society of America Abstracts with Programs 27: A59.

Larsen, P. L., Bierman, P. R., Stone, B. D. and Caffee, M. (ms.) In situ production rates of cosmogenic ${ }^{10} \mathrm{Be}$ and ${ }^{26} \mathrm{Al}$ over the past $21.5 \mathrm{ky}$ from the terminal moraine of the Laurentide ice sheet, north-central New Jersey. Submitted to Geological Society of America Bulletin.

Laughlin, A. W., Poths, J., Healey, H. A., Reneau, S. and WoldeGabriel, G. 1994 Dating of Quaternary basalts using cosmogenic ${ }^{3} \mathrm{He}$ and ${ }^{14} \mathrm{C}$ methods with implications for excess ${ }^{40} \mathrm{Ar}$ : Geology 22: 135-138.

Lin, J.-L., Verosub, K. L. and Roberts, A. P. 1994 Decay of the virtual dipole moment during polarity transitions and geomagnetic excursions. Geophysical Research Letters 21: 525-528.

Liu, B., Phillips, F. M., Fabryka-Martin, J. T., Fowler, M. M. and Stone, W. D. 1994 Cosmogenic ${ }^{36} \mathrm{Cl}$ accumulation in unstable landforms I: Effects of the thermal neutron distribution. Water Resources Research 30: 3115-3125.

Mankinen, E. A. and Champion, D. E. 1993 Latest Pleistocene and Holocene geomagnetic paleointensity on Hawaii. Science 262: 412-416.

Marti, K. and Craig, H. 1987 Cosmic-ray produced neon and helium in the summit lavas of Maui. Nature 325: 335-337.

Masarik, J. and Reedy, R. C. 1994a Effects of bulk composition on nuclide production processes in meteorites. Geochimica et Cosmochimica Acta 58: 53075317.

1994b Simulation of cosmogenic nuclide production in terrestrial rocks. In Abstracts of the 8th International Conference on Geochronology, Cosmochronology and Isotope Geology. USGS Circular 1107: 204.

1995 Terrestrial cosmogenic-nuclide production systematics calculated from numerical simulations. Earth and Planetary Science Letters 136: 381-396.

Mazaud, A., Laj, C., Bard, E., Arnold, M. and Tric, E. 1991 Geomagnetic field control of ${ }^{14} \mathrm{C}$ production over the last $80 \mathrm{ka}$ : Implications for the radiocarbon time scale. Geophysical Research Letters 18: 18851888.

McElhinny, M. W. and Senanayake, W. E. 1982 Variations in the geomagnetic dipole 1: The past 50,000 years. Journal of Geomagnetism and Geoelectricity 34: 39-51.

McHargue, L. R. and Damon, P. E. 1991 The global beryllium 10 cycle. Reviews of Geophysics 29: 141-158.

Merrill, R. T. and McElhinny, M. W. 1983 The Earth's Magnetic Field, its History, Origin and Planetary Perspective. $401 \mathrm{p}$.

Merrill, R. T. and McFadden, P. L. 1994 Geomagnetic field stability: Reversal events and excursions. Earth and Planetary Science Letters 121: 57-69.

Meynadier, L., Valet, J.-P., Weeks, R., Shackleton, N. J. and Hagee, V. L. 1992 Relative geomagnetic intensity of the field during the last $140 \mathrm{ka}$. Earth and Planetary Science Letters 114: 39-57.

Middleton, R., Brown, L., Dezfouly-Arjomandy, B. and Klein, J. 1993 On ${ }^{10} \mathrm{Be}$ standards and the half life of ${ }^{10} \mathrm{Be}$. Nuclear Instruments and Methods in Physics Research B82: 399-403.

Moniot, R. K., Kruse, T. H., Tuniz, C., Savin, W., Hall, G. S., Milazzo, T., Pal, D. and Herzog, G. F. 1983 The ${ }^{21} \mathrm{Ne}$ production rate in stony meteorites estimated from ${ }^{10} \mathrm{Be}$ and other radionuclides. Geochimica et Cosmochimica Acta 47: 1887-1895.

Nakamura, T., Sugita, H., Imamura, M., Uwamino, Y., Nagai, H. and Kobayashi, K. 1991 Measurement of the long-lived ${ }^{26} \mathrm{Al}$ production cross section in the ${ }^{27} \mathrm{Al}(\mathrm{n}, 2 \mathrm{n})$ reaction. Physical Review C43: 1831-1837.

Negrini, R. M., Erbes, D. B., Roberts, A. P., Verosub, K. L., Sarna-Wojcicki, A. M. and Meyer, C. 1994 Repeating waveforms initiated by a 150 ka geomagnetic excursion in western North America: Implications for field behavior during polarity transitions and subsequent secular variation. Journal of Geophysical Research 99: 24105-24119.

Negrini, R. M., Verosub, K. L. and Davis, J. O. 1987 Long-term non-geocentric axial dipole directions and a geomagnetic excursion from the Middle Pleistocene sediments of the Humboldt River Canyon, Pershing County, Nevada, U.S.A. Journal of Geophysical Research 92: 10617-10628.

1988 The middle to late Pleistocene geomagnetic field recorded in fine-grained sediments from Summer Lake, Oregon and Double Hot Springs, Nevada, U.S.A. Earth and Planetary Science Letters 87: 173192.

Niedermann, S., Graf, T., Kim, J. S., Kohl, C. P., Marti, K. and Nishiizumi, K. 1994 Cosmic-ray-produced ${ }^{21} \mathrm{Ne}$ in terrestrial quartz: The neon inventory of Sierra Nevada quartz separates. Earth and Planetary Sciences 125: 341-355.

Niedermann, S., Graf, T. and Marti, K. 1993 Mass spectrometric identification of cosmic-ray-produced neon in terrestrial rocks with multiple neon components. Earth and Planetary Science Letters 118: 65-73.

Nishiizumi, K., Elmore, D., Ma, X. Z. and Arnold, J. R. $1984{ }^{10} \mathrm{Be}$ and ${ }^{36} \mathrm{Cl}$ depth profiles in an Apollo 15 drill core. Earth and Planetary Science Letters 70: 157163.

Nishiizumi, K., Finkel, R. C., Klein, J. and Kohl, C. P. (ms.) Cosmogenic production of ${ }^{7} \mathrm{Be}$ and ${ }^{10} \mathrm{Be}$ in water targets. Submitted to Journal of Geophysical Research.

Nishiizumi, K., Klein, J., Middleton, R. and Arnold, J. R. $1984{ }^{26} \mathrm{Al}$ depth profile in Apollo 15 drill core. Earth and Planetary Science Letters 70: 164-168. 
Nishiizumi, K., Klein, J., Middleton, R. and Craig, H. 1990 Cosmogenic ${ }^{10} \mathrm{Be},{ }^{26} \mathrm{Al}$ and ${ }^{3} \mathrm{He}$ in olivine from Maui lavas. Earth and Planetary Science Letters 98: 263-266.

Nishiizumi, K., Kohl, C. P., Arnold, J. R., Klein, J., Fink, D. and Middleton, R. 1991a Cosmic-ray produced ${ }^{10} \mathrm{Be}$ and ${ }^{26} \mathrm{Al}$ in Antarctic rocks: Exposure and erosion history. Earth and Planetary Science Letters 104: 440-454.

Nishiizumi, K., Kohl, C. P., Shoemaker, E. M., Arnold, J.R., Klein, J., Fink, D. and Middleton, R. 1991b In situ ${ }^{10} \mathrm{Be}-{ }^{26} \mathrm{Al}$ exposure ages at Meteor Crater, Arizona. Geochimica et Cosmochimica Acta 55: 2699-2703.

Nishiizumi, K., Lal, D., Klein, J., Middleton, R. and Arnold, J. R. 1986 Production of ${ }^{10} \mathrm{Be}$ and ${ }^{26} \mathrm{Al}$ by cosmic rays in terrestrial quartz in situ and implications for erosion rates. Nature 319: 134-135.

Nishiizumi, K., Murty, S. V. S., Marti, K. and Arnold, J. R. 1985 When did the average cosmic ray flux increase? 19th International Cosmic Ray Conference, La Jolla. SH 7.1-4: 379-381.

Nishiizumi, K., Reedy, R. C. and Arnold, J. R. 1990 Depth profiles of radionuclide production in solids with $2 \pi$ geometry. Workshop on Cosmogenic Nuclide Production Rates, Lunar and Planetary Institute Technical Report 90-05: 96-97.

Nishiizumi, K., Regnier, S. and Marti, K. 1980 Cosmic ray exposure ages of chondrites, pre-irradiation and constancy of cosmic ray flux in the past. Earth and Planetary Science Letters 50: 156-170.

Nishiizumi, K., Winterer, E. L., Kohl, C. P., Lal, D., Arnold, J. R., Klein, J. and Middleton, R. 1989 Cosmic ray production rates of ${ }^{10} \mathrm{Be}$ and ${ }^{26} \mathrm{Al}$ in quartz from glacially polished rocks. Journal of Geophysical Research 94: 17,907-17915.

O’Brien, K., Friedberg, W., Sauer, H. and Smart, D. (Plenary lecture) Atmospheric cosmic rays and solar energetic particles at aircraft altitudes. International Symposium on the Natural Radiation Environment, Montréal, Canada, 9 June 1995.

Ohno, M. and Hamano, Y. 1993 Geomagnetic poles over the last 10,000 years. Geophysical Research Letters 19: $1715-1718$.

Olinger, C. T., Poths, J., Nishiizumi, K., Kohl, C. P., Finkel, R. C., Caffee, M. W., Southon, J. and Proctor, I. 1992 Attenuation lengths of cosmogenic production of ${ }^{26} \mathrm{Al},{ }^{10} \mathrm{Be}$ and ${ }^{21} \mathrm{Ne}$ in Bandelier Tuff. EOS 73: 185 .

Phillips, F. M., Zreda, M. G., Elmore, D. and Sharma, P. (ms.) A reevaluation of cosmogenic ${ }^{36} \mathrm{Cl}$ production rates in terrestrial rocks. Submitted to Geophysical Research Letters.

Phillips, F. M., Zreda, M. G., Smith, S. S., Elmore, D., Kubik, P. W., Dorn, R. I. and Roddy, D. J. 1991 Age and geomorphic history of Meteor Crater, Arizona, from cosmogenic $\mathrm{Cl}-36$ in rock varnish. Geochimica et Cosmochimica Acta 55: 2695-2698.

Poreda, R. J. and Cerling, T. E. 1992 Cosmogenic neon in recent lavas from the western United States. Geophysical Research Letters 19: 1863-1866.

Reedy, R. C., Arnold, J. R. and Lal, D. 1983 Cosmic ray record in solar system matter. Annual Review of $\mathrm{Nu}$ clear and Particle Science 35: 505-537.

Reedy, R. C., Lal, D., Laffoon, M., Nishiizumi, K., Arnold, J. R., Elmore, D., Kubik, P., Klein, J., Middleton, R. and Englert, P. 1988 Simulations of the cosmic-ray production of radionuclides in terrestrial rocks. Progress at LAMPF 1987, Los Alamos National Laboratory Report LA-11339: 148-154.

Reedy, R. C., Nishiizumi, K. and Arnold, J. R. 1990 Cross sections for galactic-cosmic-ray-produced nuclides. Workshop on Cosmogenic Nuclide Production Rates. LPI Technical Report 90-05: 102-103.

Reedy, R. C., Nishiizumi, K., Klein, J., Davis, R., Middleton, R., Lal, D., Arnold, J. R., Kubik, P., Jull, A. T. J., Englert, P. A. J. and Elmore, D. 1994 Production of cosmogenic nuclides by muons. Abstracts of the 8th International Conference on Geochronology, Cosmochronology and Isotope Geology. USGS Circular 1107: 262

Reedy, R. C., Nishiizumi, K., Lal, D., Arnold, J. R., Englert, P. A. J., Klein, J., Middleton, R., Jull, A. J. T. and Donahue, D. J. 1994 Simulations of terrestrial in-situ cosmogenic-nuclide production. Nuclear Instruments and Methods in Physics Research B92: 297-300.

Reedy, R. C., Tuniz, C. and Fink, D. 1994 Report on the workshop on production rates of terrestrial in-situproduced cosmogenic nuclides. Nuclear Instruments and Methods B92: 335-339.

Roberts, A. P., Verosub, K. L. and Negrini, R. M. 1994 Middle/Late Pleistocene relative paleointensity of the geomagnetic field from lacustrine sediments, Lake Chewaucan, western United States. Geophysical Journal International 118: 101-110.

Sarda, P., Staudacher, T., Allegre, C. J. and Lecomte, A. 1993 Cosmogenic neon and helium at Réunion: Measurement of erosion rate. Earth and Planetary Science Letters 119: 405-417.

Shea, D. and Smart, F. 1983 A world grid of calculated cosmic ray vertical cutoff rigidities of 1980.18 th International Cosmic Ray Conference, Conference $\mathrm{Pa}$ pers 3: 415 .

Shibata, S., Imamura, M., Nagai, H., Kobayashi, K., Sakamoto, K., Furukawa, M. and Fujiwara, I. 1993 Measurements of ${ }^{10} \mathrm{Be}$ and ${ }^{26} \mathrm{Al}$ production cross sections with $12 \mathrm{GeV}$ protons by accelerator mass spectrometry. Physical Review C 48: 2617-2624.

Shibata, S., Shibata, T., Imamura, M., Uwamino, Y., Ohkubo, T., Satoh, S., Morikawa, N. and Nogawa, N. (ms.) Measurement of production cross section of tritium from oxygen using semimono-energetic $\mathrm{p}-\mathrm{Be}$ and p-Li neutrons. Submitted to Radiochimica.

Sisterson, J. M., Jull, A. J. T., Beverding, A., Koehler, A. M., Castaneda, C., Vincent, J., Donahue, D. J., Englert, P. A. J., Gans, C., Young, J. and Reedy, R.C. 1994 
Proton production cross sections from ${ }^{14} \mathrm{C}$ from silicon and oxygen: Implications for cosmic ray studies. Nuclear Instruments and Methods in Physics Research B92: 510-512.

Staudacher, T. and Allégre, C. J. 1993 Ages of the second caldera of Piton de la Fournaise volcano (Réunion) determined by cosmic ray produced ${ }^{3} \mathrm{He}$ and ${ }^{21} \mathrm{Ne}$. Earth and Planetary Science Letters 119: 395-404.

Sternberg, R. S. 1989 Secular variation of archaeomagnetic direction in the American Southwest. Journal of Geophysical Research 94: 527-546.

1992 Radiocarbon fluctuations and the geomagnetic field. In Taylor, R. E., Long, A. and Kra, R., eds., $R a$ diocarbon After Four Decades: An Interdisciplinary Perspective. New York, Springer Verlag: 93-116.

Sternberg, R. S. and Damon, P. E. 1992 Implications of dipole moment secular variation from 50-10 ka for the radiocarbon record. Radiocarbon 34(2): 189-198.

Sternberg, R. S., Deaver, W. L., Kuter, E. A. and Kiley, A. L. (ms.) A relational North American archaeomagnetic database. Submitted to Journal of Geomagnetism and Geoelectricity.

Strack, E., Heisinger, B., Dockhorn, B., Hartmann, F. J., Korschinek, G., Nolte, E., Morteani, G., Petitjean, C. and Neumaier, S. 1994 Determination of erosion rates with cosmogenic ${ }^{26} \mathrm{Al}$. Nuclear Instruments and Methods B92: 317-320.

Stuiver, M., Braziunas, T. F., Becker, B. and Kromer, B. 1991 Climatic, solar, oceanic and geomagnetic influences on Late-Glacial and Holocene atmospheric ${ }^{14} \mathrm{C}$ / ${ }^{12} \mathrm{C}$ change. Quaternary Research 35: 1-24.

Stuiver, M., Grootes, P. M. and Braziunas, T. F. 1995 The GISP2 ${ }^{18} \mathrm{O}$ climate record of the past 16,500 years and the role of the Sun, ocean and volcanoes. Quaternary Research 44: 341-354.

Stuiver, M. and Reimer, P. J. 1993, Extended ${ }^{14} \mathrm{C}$ data base and revised CALIB $3.0{ }^{14} \mathrm{C}$ age calibration program. In Stuiver, M., Long, A. and Kra, R. S., eds., Calibration 1993. Radiocarbon 35(1): 215-230.

Swanson, T. W., Caffee, M., Finkel, R., Harris, L., Southon, J., Zreda, M. and Phillips, F. M. 1993 Establishment of new production parameters for chlorine-36 dating based on the deglaciation history of Whidbey Island, Washington. GSA Abstracts with Programs, Annual Meeting, Boston 25: A-61.

Swanson, T. W., Sharma, P., Phillis, F. M. and Zreda, M. 1992 Determination of Chlorine-36 production rates from the deglaciation history of Whidbey Island, WA. Symposium on Accelerator Mass Spectrometry: Applications of Rare Isotopes as Tracers in Science and Technology, American Chemical Society, Division of Nuclear Chemistry and Technology, San Francisco.

Swanson, T. W., Zreda, M., Phillips, F. M., Caffee, M., Finkel, R. and Southon, J., in press, Determination of ${ }^{36} \mathrm{Cl}$ production rates from the deglaciation history of Whidbey and Fidalgo Islands, Washington. Quaternary Research.
Tauxe, L. 1993 Sedimentary records of relative paleointensity of the geomagnetic field: Theory and practice. Reviews of Geophysics 31: 319-354.

Tric, E., Valet, J.-P., Tucholka, P., Paterne, M., Labeyrie, L., Guichard, F., Tauxe, L. and Fontugne, M. $1992 \mathrm{~Pa}$ leointensity of the geomagnetic field during the last 80,000 years. Journal of Geophysical Research 97: 9337-9351.

Trull, T. W., Brown, E. T., Marty, B., Raisbeck, G. M. and Yiou, F. 1995 Accumulation of cosmogenic ${ }^{10} \mathrm{Be}$ and ${ }^{3} \mathrm{He}$ in quartz from Pleistocene beach terraces in Death Valley: Implications for cosmic-ray exposure dating of young surfaces in hot climates. Chemical Geology 119: 191-207.

Trull, T. W., Kurz, M. D. and Jenkins, W. J. 1991 Diffusion of cosmogenic ${ }^{3} \mathrm{He}$ in olivine and quartz: Implications for surface exposure dating. Earth and Planetary Science Letters 103: 241-256.

Valet, J.-P. and Meynadier, L. 1993 Geomagnetic field intensity and reversals during the past four million years. Nature 366: 234-238.

Verosub, K. L. 1988 Geomagnetic secular variation and the dating of Quaternary sediments. In Easterbrook, D., ed., Dating Quaternary Sediments. Geological Society of America Special Paper 227: 123-138.

1989 Detrital remanent magnetism. In James, D.E., ed., The Encyclopedia of Solid Earth Physics. Reinhold, New York, Van Nostrand: 215-218.

in press, Paleomagnetic dating in Quaternary Geochronology: Applications in Quaternary Geology and Paleoseismicity. In Lettis, W., Noller, J. and Sower, J., eds., Geological Society of America Special Paper.

Verosub, K. L. and Banerjee, S. K. 1977 Geomagnetic excursions and their paleomagnetic record. Reviews of Geophysics and Space Physics 15: 145-155.

Verosub, K. L., Mehringer, P. J. J. and Waterstraat, P. 1986 Holocene secular variation in western North America: Paleomagnetic record from Fish Lake, Harney Co., Oregon. Journal of Geophysical Research 91: 3609-3623.

Wohlfarth, B., Björck, S., Possnert, G. and Brunnberg, L. 1995 A comparison between radiocarbon dated Late Weichselian calendar-year chronologies. Journal of Coastal Research Special Issue.

Yamashita, M., Stephens, L. D. and Patterson, H. W. 1966 Cosmic-ray-produced neutrons at ground level: Neutron production rate and flux distribution. Journal of Geophysical Research 71: 3817-3834.

Zreda, M. G. 1994 Development and calibration of the cosmogenic ${ }^{36} \mathrm{Cl}$ surface exposure dating method and its application to late Quaternary glaciations. Ph.D. thesis, New Mexico Institute of Mining and Technology, Socorro.

Zreda, M. G., Phillips, F. M., Elmore, D., Kubik, P. W., Sharma, P. and Dorn, R. I. 1991 Cosmogenic chlorine36 production rates in terrestrial rocks. Earth and Planetary Science Letters 105: 94-109. 